\title{
Bio-Based Products
}

\section{Suggestions for Ecolabel Criteria and Standards in Line with Sustainable Development Goals}

\author{
Simone Wurster, Technische Universität Berlin, Berlin, Germany \\ Luana Ladu, Technische Universität Berlin, Berlin, Germany \\ Dhandy Arisaktiwardhana, Technische Universität Berlin, Berlin, Germany
}

\begin{abstract}
Communicating the related environmental benefits of bio-based products to consumers represents a key component of their market uptake. In this regard, the use of ecolabels ISO 14024 Type I play a crucial role. This article identifies and analyzes different criteria proposed by ecolabels for conducting a sustainability assessment of bio-based products considering its entire lifecycle. A comparison of the selected criteria with existing indicators ruled out by the SDGs is proposed. Through expert consultation, the suitability of existing ecolabel criteria for bio-based products has been tested for four applications of biobased products: food packaging from PLA; biobased automotive components; bio-based mulch film; and bio-based insulation material.
\end{abstract}

\section{KEYWORDS}

Bio-Based Products, Bioeconomy, Circular Economy, Ecolabels, Environmental Certification, SDGs, Standards, Sustainability

\section{INTRODUCTION TO THE UNITED NATIONS SUSTAINABILITY GOALS, ECOLABELLING AND THE BIOECONOMY}

In 2016, the United Nations' Sustainability Goals (SDGs) were proposed and designed, comprising 17 worldwide agreed goals to make planet earth more sustainable.

The importance of environmental labelling was recognized in 1992, during the Second Earth Summit (Rio Summit). The resulting Agenda 21 mentions environmental labelling as a tool to promote Sustainable Development (SD) (Horne, 2009; United Nations, 1992).

Ecolabelling provides consumers with explicit information about the environmental performance of a product and directs their buying behaviour toward sustainable choices (European Commission, 2012). It plays also an important role as a government policy instrument to establish information guidelines for consumers on sustainable consumption (BIO Intelligence Service, 2012; Schader et al., 2011). Therefore, ecolabels address the goal of sustainable consumption and production patterns, corresponding to the 12th goal of SD (United Nations, 2015). This article will show further links between ecolabels and the SDGs.

Various links between the SDGs and the bioeconomy have been identified by previous publications. While Gawel et al. (2019) argue that the bioeconomy has a positive impact on the SDGs, others argue that its application has both positive and negative impacts on the achievement of SDG targets (see Heimann, 2019, Nunes et al., 2016). For this reason, bioeconomy products with positive 
environmental impacts require appropriate communication and marketing tools in order to convince the consumers of its benefits.

Bio-based products are one of the bioeconomy sectors (European Commission, 2012, p. 5). According to CEN (2014), they are defined as products produced entirely or partly from biomass (plant, forestry or animal origin).

A key component for the market uptake of bio-based products is to communicate the related environmental benefits to the consumer. Ladu and Blind (2017) argue that labels, in particularly ecolabels are an essential vehicle to communicate the benefits of bio-based products to consumers, especially if predefined sustainability criteria are met and verified through a certification process.

This article starts with a literature review, followed by information on the research objectives and methodologies. Afterwards, selected ecolabel criteria are described and suggestions for ecolabel criteria and labels for a number of bio-based products in line with the SDGs are made. The article ends with suggestions for further steps and conclusions.

This research was carried out within the framework of the EU project STAR-ProBio (http://www. star-probio.eu/, Grant Agreement Number 727740). It was supplemented by additional literature and an outlook on the German project ConCirMy (Configurator for the Circular Economy, funded by the German Ministry of Education and Research, funding code: 033R236E ReziProK). This article makes use of material presented by the authors at the EURAS Conference 2019.

\section{LITERATURE REVIEW ON THE SDGS AND ECOLABELS}

\section{Current Contributions of the Bioeconomy to the SDGs}

Various relations between the bioeconomy and the SDGs exist already. To support SDG 2 (Zero Hunger), the efficient use of biomass as a sustainable energy source can supply energy needs for beneficiaries to make, convert and eat food, which tackles the goal to end hunger, obtain food security and improve nutrition (WFP, 2019). The use of biomass waste, use of wastewater, use of marine fauna (fish) and flora (algae) and an increasing importance of biodiversity can contribute to the achievement of SDG 6,12, 14 and 15 (referring to clean water, responsible consumption, life on land and below water, Biobased Industries Consortium, 2018). In the transportation sector, the use of bioenergy can increase access to modern energy services and can reduce the use of fossil fuels (Biobased Industries Consortium, 2018), which is in line with SDG 7 on affordable and clean energy. El-Chichakli et al. (2016) describe the positive impact on the local economy through the construction of a large bio-refinery in Finland. Although the refinery only requires 200 workers to carry out the production process, the authors argue that 2,500 other jobs will be created throughout the value chain. In addition, El-Chichakli et al. (2016) argue that the recovery of organic waste and the conversion of domestic waste into biofuels, and also the conversion of $\mathrm{CO}_{2}$ emissions into chemicals and biofuels can contribute to the achievement of targets on SDG 11 and 13 on sustainable cities and climate action. Potential for additional contributions of the bioeconomy to the persuasion of the SDGs and their demonstrations by the use of targeted ecolabel criteria will be subject of this study.

\section{Benefits of Ecolabels and Standards}

Ecolabels play an import role in promoting eco-friendly consumption. The reason is that most ecolabelled products are credence goods, implying that the valued attributes they contain are not observable to the consumer even after purchase or consumption (Daugbjerg et al., 2014). As Figure 1 shows, eco-friendly consumption is influenced by a set of consumer-related factors, in which "Trust in the ecolabel" and "Knowledge on eco-friendly aspects" play an important role.

Ideally, environmental labels are based on transparent criteria and are awarded by an independent third party (e.g. the EU Ecolabel). By acquiring these labels, products show compliances with technical specifications and sustainability criteria. Considering that consumers accept the label as one means of proof of compliance with the technical specifications, standards function as an important foundation of trust-worthy ecolabels. 
As a form of ISO's contributions in line with the 12th SDG related to consumption and sustainable production, ISO has set standards for environmental labelling in the ISO 14020 series (ISO, 2018a). The ISO 14020 series consists of three types of standards for voluntary environmental labels (Horne, 2009), namely ISO 14024: 2018 (for Type I - Environmental Labels), ISO 14021: 2016 (for Type II - Environmental Labelling), and ISO 14025: 2006 (for Type III - Environmental Declaration). The three standards provide guiding principles for the development and application of environmental labels and self-declarations and conceptualize third-party certification programs, which help verify environmental claims and thus encourage consumers to make better choices. In addition, new fields of action are emerging, which require the development of new standards and specifications. This article will provide more insight in this regard.

The application of ecolabelling through the use of ISO standards can ensure consumers to obtain reliable purchase information from producers regarding environmental claims. This is because the ISO standards have global recognition and involve various stakeholders in determining objective criteria (ISO, 2012; ISO, 2018b). According to ISO 14024:2018, ecolabelling is a type of labelling that follows Type I environmental labelling, based on multi-criteria and life-cycle seals of approval (ISO, 2018c). The standard specifies principles and procedures to establish a Type I environmental labelling program, including determining product categories, product environmental criteria, and product function characteristics; and to evaluate and prove conformity. The standard also establishes certification procedures for labelling. Type I environmental labelling is a third-party certified product environmental labelling scheme that refers to the determination of a set of criteria by a private or public environmental labelling program (Horne, 2009). The third-party certifier issues and controls the use of logos or marks for the certified product (Ibanez, 2016; ISO, 2018c). A third-party certifier or ecolabelling body that awards the label (a logo or mark) can come from government organizations or private non-commercial organizations (Ibanez, 2016; ISO, 2018c). Therefore, the ecolabelling body as a third-party certifier has an important role in the ecolabelling scheme to award label (a logo or

Figure 1. The relationship between ecolabels and the purchase of eco-friendly products. Source: own figure inspired by Daugbjerg et al. (2014)

Label-related factors

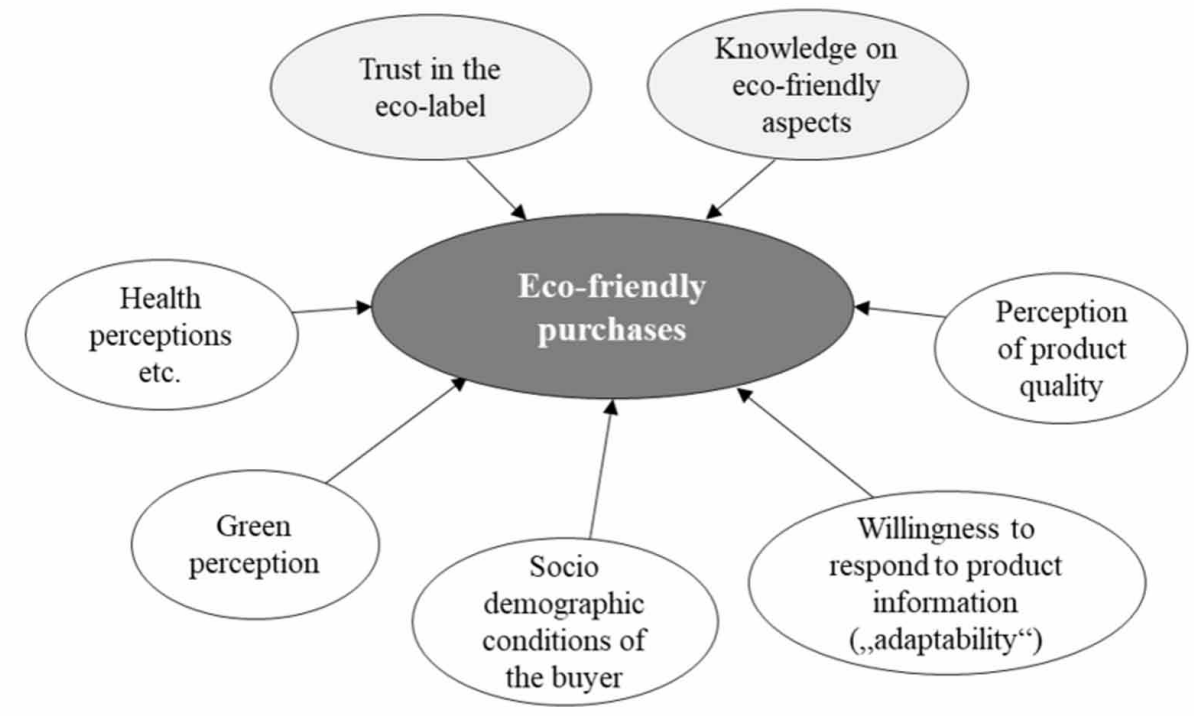


mark) to the product based on the fulfilment of a set of criteria determined by the private or public environmental labelling program. Examples of Type I environmental labelling are the EU Ecolabel and the German Blue Angel.

\section{RESEARCH OBJECTIVES AND METHODOLOGIES}

Taking up the technical developments for establishing a sustainable, bio-based economy, the present study aims to gain information on how ecolabels and standards can support the market acceptance of bio-based products. Also insight will be given to the extent to which proposed sets of sustainability measures have similar or different characteristics in comparisons of selected products. Four types of bio-based products were selected for the studies:

- $\quad$ Food packaging made of polylactic acid (PLA)

- Bio-based automotive components

- Bio-based mulch film

- Bio-based insulation material and insulating materials.

PLA is a bio-based, biodegradable thermoplastic with a wide range of applications, including packaging for fresh foods such as yoghurt, desserts and meat products; paper bags and cartons with plastic windows for baked goods; tableware as well as label and wrapping films (see Green \& Kunnemann, 2006). At 10.3\%, PLA has the fourth-largest share of the global bioplastics market and also accounts for more than $25 \%$ of the world market for biodegradable bioplastics (see European Bioplastics, 2018).

The automotive sector has potential for increased bio-based materials, some of which are already successfully implemented. According to an analysis carried out in 2010, an average car consists of approximately $150 \mathrm{~kg}$ of plastics and plastic composite elements (see CE Delft, 2017) and raises the question of suitable bio-based alternatives. Examples of applications for bio-based solutions in the automotive sector, in general, include bio-resins, fibre-based solutions for the interior and composite materials (see e.g. CE Delft, 2017). Another new field of application for bio-based materials in the automobile industry are tires, which the newly launched ConCirMy project aims to analyze. Of particular importance for this article were a) side doors with interior trim made of composite materials with natural fibres such as flax, hemp, linen and a bio-based resin, b) mirror and indicator cover made of bio-based polyamides and c) vehicle interiors made of polypropylene in combination with natural fibres.

Mulch films are used for the cultivation of agricultural products, e.g. asparagus. Biodegradable versions offer two main advantages. First, biodegradation of bio-based products in the soil is not expected to produce ecotoxic effects. Bio-based biodegradable mulch films do not contain heavy metals that could cause such effects (see De Wilde, 2002). The second advantage relates to the afteruse phase because the degradability eliminates the need to remove the films from the agricultural soil after use. Bio-based plastics currently account for a relatively small share of the agricultural plastics market. However, a strong growth is expected for the next few years (see European Bioplastics, 2016).

Stimulated by the introduction of sustainability concepts in building/construction design, research into the development of insulating materials from natural or recycled materials has also increased. Bio-based materials here are in particular wood fibers, cellulose, wool, hemp and straw, supplemented by "unconventional" materials such as reed, maize, cotton, oil palm fibers, pineapple leaves, rice and sunflowers (see Asdrubali et al., 2015). Due to the importance of the construction sector as a major polluter of greenhouse gas emissions, bio-based products from this sector were also included in the study. 
After selecting products for the analysis, we conceptualized and implemented a research strategy with five elements: 1 . literature review and research on the SDGs, 2. analysis of the existing ecolabels landscape, 3. preparation, conduct and analysis of experts interviews in four areas of bio-based products, 4. development of recommendations for ecolabel criteria and standardisation and 5. deriving comparisons. Utilizing the Ecolabel Index, which provides information on 465 ecolabels from 99 countries and 25 industry sectors, we identified the most relevant labels for bio-based products. This research paved the way for the development of an interview guide to be used in the in-depth case studies analysis. Carrying out semi-structured interviews (Adams, 2015) with professionals dealing with the four product groups of our analysis was the following step. The interview guide consisted of six sections: background of the interviewee(s), framework conditions, ecolabels and sustainability standards. In addition to open questions, a section included a list of criteria identified in the analyses of the ecolabel landscape for deeper analyses on their suitability in the areas of our research. Interviewees were selected to represent a wide range of stakeholders (see Table 1).

The interviews took place between May and September 2018. The results were given more depth by the analysis of additional sources provided by the interviewees. Based on all the gathered information, we finally developed a set of recommendations, supporting the use of the four case study products, enriched by comparisons and an analysis of the contribution to addressing the United Nations' sustainability goals.

\section{SELECTED ECOLABEL CRITERIA}

\section{Foundations}

The first chapters introduced ecolabels, environmental standards and their links to the SDGs. The following chapters represent our analysis of these areas for the selected products. A problem of biobased products, in general, is the lack of evidence of their specific environmental, social and economic sustainability. Therefore, the development of tools and indicators is of high relevance (see e.g. Ladu and Blind, 2017). An initial goal of our research was therefore to identify suitable ecolabel criteria.

Initially, suitable labels were selected by using the following search terms in the Ecolabel Index: "bio" (52 hits), "bio-based" (2 hits), biobased" (2 hits), sustainable (34 hits), "construction" (24 hits), "building" (62 hits) "waste" (29 hits) and "plastics" (4 hits). Based on further screenings, we analysed 42 ecolabels (see Table 2), including, for example, the EU Ecolabel, the German Blue Angel, the Carbon Trust Footprint Label and the Nordic Swan regarding relevant basic criteria.

The following sections provide a summary of relevant existing criteria in selected ecolabels, which are grouped as follows (see also STAR-ProBio, 2018a):

a) Sustainability criteria: environmental, social and economic criteria

b) Additional criteria: percentage of bio-based content and fitness for use

A specific approach to assess the environmental impact of a product, based on various environmental criteria, is provided by life cycle assessments (LCA) (see box 1).

The application of LCA varies between the different label types. Type III labels, which may build on a single criterion or multi-criteria sets, use LCA but do not provide thresholds.

\section{SUSTAINABILITY CRITERIA}

\section{Sustainable Sourcing of Biomass}

The Renewable Energy Directive (RED) specifies legally binding requirements on sustainable sourcing of biomass for bioenergy, liquid biofuels and bioliquids. The most important requirements are: 
Table 1. Overview of participants to the interview series

\begin{tabular}{|l|l|l|c|c|c|}
\hline Case study and Interviewees & $\begin{array}{l}\text { Food } \\
\text { packaging } \\
\text { made of PLA }\end{array}$ & $\begin{array}{l}\text { Bio- } \\
\text { based car } \\
\text { components }\end{array}$ & $\begin{array}{l}\text { Bio-based } \\
\text { mulch film }\end{array}$ & $\begin{array}{l}\text { Bio-based } \\
\text { insulation } \\
\text { material }\end{array}$ & Total \\
\hline Producers, retailers etc. & 1 & 2 & 5 & 2 & 10 \\
\hline $\begin{array}{l}\text { Certification bodies, testing } \\
\text { laboratories, standards bodies }\end{array}$ & 1 & 2 & -1 & - & 3 \\
\hline $\begin{array}{l}\text { Procurement (e.g. farmers using } \\
\text { mulch film, food sector) }\end{array}$ & 4 & -2 & 2 & - & 6 \\
\hline Other (government, research) & -3 & 2 & - & 1 & 3 \\
\hline Total & 6 & 6 & 7 & 3 & 22 \\
\hline
\end{tabular}

${ }^{1}$ The project consortium itself has expertise in this field.

"Instead of a public procurer, an expert of a governmental organisation with a specific focus on bio-based car components was contacted (see "Other").

${ }^{3}$ The case study was enriched by an interview with a representative of a big stakeholder network. Due to the high consistency of the results of the first interviews, it was then decided to finish the interview series on food packaging.

Table 2. Selected ecolabels for bio-based products

\begin{tabular}{|c|c|c|c|c|c|}
\hline $123 \mathrm{~g} \mathrm{CO}_{2}$ & ECOCERT & GreenPla & Nordic Ecolabel & RSB & Terracycle \\
\hline Blauer Engel & Effinature & $\begin{array}{c}\text { Gütezeichen } \\
\text { Kompost RAL }\end{array}$ & NSF & RSPO & $\begin{array}{l}\text { UL Environment } \\
\text { Multi-Attribute } \\
\text { Certification }\end{array}$ \\
\hline $\begin{array}{c}\text { Carbon Neutral } \\
\text { Product } \\
\text { Certification }\end{array}$ & EU Ecolabel & IMO Certified & OK biobased & $\begin{array}{c}\text { SCS certified } \\
\text { Recycled Content }\end{array}$ & $\begin{array}{c}\text { UL } \\
\text { Environmental } \\
\text { Claim Validation }\end{array}$ \\
\hline $\begin{array}{c}\text { Cradle to Cradle } \\
\text { Certified }(\mathrm{CM}) \\
\text { Products }\end{array}$ & FAIRTRADE & LEED & $\begin{array}{c}\text { OK } \\
\text { Biodegradable } \\
\text { WATER }\end{array}$ & Seedling & $\begin{array}{c}\text { UPS Eco } \\
\text { Responsible } \\
\text { Packing } \\
\text { Programme }\end{array}$ \\
\hline $\begin{array}{l}\text { Der Grüner } \\
\quad \text { Punkt }\end{array}$ & FSC & Level & Öko control & $\begin{array}{l}\text { SFC Member } \\
\text { Seal }\end{array}$ & $\begin{array}{l}\text { USDA Certified } \\
\text { Biobased Product }\end{array}$ \\
\hline DGNB & $\begin{array}{l}\text { Green America } \\
\text { Approved for } \\
\text { People and } \\
\text { Planet }\end{array}$ & natureplus & $\begin{array}{l}\text { PAS } 100 \\
\text { Certified }\end{array}$ & $\begin{array}{c}\text { Smart Approved } \\
\text { WaterMark }\end{array}$ & $\begin{array}{c}\text { VCS Verified } \\
\text { Carbon Standard }\end{array}$ \\
\hline $\begin{array}{l}\text { earth advantage } \\
\text { institute }\end{array}$ & $\begin{array}{c}\text { GreenCircle } \\
\text { Certified }\end{array}$ & Naturland & PEFC & SMART certified & VIBE \\
\hline
\end{tabular}

\section{Box 1. LCA}

\section{Life cycle assessment and bio-based products}

According to ISO (2006), Life Cycle Assessments (LCA) are "compilation(s) and evaluation(s) of the inputs, outputs and the potential environmental impacts of a product system throughout its life cycle". The two general standards ISO 14040 and 14044 form the foundation for this. EN 16760 then describes how to deal with the special features of the bio-based part of a bio-based product in a life cycle assessment (see CEN, 2015). The Environmental Product Declarations (EPDs), ISO label Type III are a direct application of LCAs. Many bio-based products perform better than the conventional alternative over their entire life cycle (see Wurster et al., 2018). 
- The reduction of greenhouse gas emission through the use of biofuels and bioliquids shall be at least $50 \%$ compared to fossil fuels (60\% for biofuels produced in plants whose operation started after 1st January 2017) (see European Commission, 2018b)

- (Sustainable) biofuels and bioliquids must not be produced from raw material derived from soils with high biodiversity

- (Sustainable) biofuels and bioliquids shall not be made from raw material obtained from soils with a high carbon content (e.g. wetlands or forests).

Monetary incentives are created to support compliance with these criteria. However, such guidelines do not yet exist in the markets for bio-based products. According to UBA (2018), there is no regulatory/sustainability certification for the material use of bio-based raw materials in Europe. Nevertheless, there are label pioneers, who deal with sustainable sourcing in the assessment of biobased products (e.g. the Roundtable on Sustainable Biomaterials (RSB)). In addition, three certificates containing relevant sustainability principles are to be listed: International Sustainability and Carbon Certification (ISCC) PLUS and FSC®/PEFC (see STAR Pro-Bio, 2018a). PEFC also includes social criteria and requires that genetically modified organisms are not used.

\section{Greenhouse Gas Emissions (GHG)}

To determine the impact of a product or process on climate change, the measurement of greenhouse gas emissions is often used as a proxy. GHG emissions are also often considered from a life cycle perspective. With that perspective, the GHG emissions are used in various Type III labels (e.g. the Carbon Trust Footprint Label). The ecolabel index contains 25 ecolabels that focus on the $\mathrm{CO}_{2}$ footprint of products or processes.

Various options are available for measuring the GHG emissions (see STAR-ProBio, 2018a) and the scope and methods of measuring GHG emissions varies between the schemes. For instance, indirect emissions from land use change (iLUC) are not included in the vast majority of existing schemes (see STAR-ProBio 2017 and 2018c). By contrast, following the adoption of the RED in 2009, the question of GHG emissions caused by iLUC began to arise in the EU and finally led to the adoption of an amendment to the RED in 2015. That amendment relates to the iLUC factors for biofuels per raw material that the Member States should use for reporting. Quantifying such emissions was and is the biggest problem. The use of biomass in products may help to reduce the global warming potential of our economy. Open-Bio (2016), for example, has shown that various bio-based products have the advantage of having a lower $\mathrm{CO}_{2}$ footprint in production than alternative fossil products.

\section{Toxicity}

According to ISO (2013), the term toxicity refers to the ability of a substance to have negative effects on a living organism. The importance of reduced human toxicity and environmental advantage from the users' point of view is mentioned, for example, in Peuckert and Quitzow (2017). Different labels regard toxicity as an ecolabel criterion (e.g. different categories of the EU Ecolabel and the ÖkoControl label (source: internal ecolabel database)).

\section{End-of-Life Criteria}

The significance of end-of-life criteria for consumers interested in green products can be demonstrated by various studies, e.g. TNS (2012). Depending on the product properties and the substances they may contain, several end-of-life options can be considered for bio-based products. TÜV Austria provides, for example, the labels OK biodegradable WATER, OK biodegradable SOIL and OK biodegradable MARINE. Given the partial or complete biological origin of bio-based products, their end-of-life management can be important to avoid the loss of materials that can be returned more naturally to the biological cycle. The waste hierarchy promotes the avoidance of waste or the return of materials into 
the economy. This must be taken into account when prioritising end-of-life options. However, it is also important to note that not all biologically produced materials can be added to biological cycles.

\section{Social Criteria}

The central aspects of the social ecolabel criteria relate to general social issues and the specific working conditions of the employees working in the different value chains of the entire life cycle of a biobased product. Most ecolabels have a strong focus on environmental aspects compared to social and economic ones. One of the few examples of ecolabels that include social criteria is the EU Ecolabel, which obliges corporate social responsibility to respect "fundamental principles and rights at work" in the assessment criteria for some product categories. As described in the International Labour Organisation's (ILO) Core Labour Standards, the UN Global Compact and the OECD Guidelines for Multi-National Enterprises, such social standards shall be observed by production sites along the supply chain of a product (see ILO/ITC, 2007).

Another example of good practice is shown by PEFC (no date), which, in addition to food security also demands respect for human and labour rights. The social impact of product cycles and production is taken into account through the Cradle to Cradle ${ }^{\circledR}$ label. The history of the RSPO certificate (see EIA, 2015) has revealed that, in addition to the formulating of social sustainability criteria, the assessment of appropriate compliance is also very important.

\section{Economic Criteria}

According to OECD (1995), ecolabels are mainly seals that show the environmental impacts of products. While many social criteria could be revealed with the help of our analyses, economic criteria are very rarely used in the current ecolabel landscape. In the following, three economic criteria will be presented.

\section{Energy Efficiency of the Production Stage}

Compared to other ecolabels, the Cradle to Cradle ${ }^{\circledR}$ concept considers economic criteria (e.g. the use of materials, energy and water in the production). Compared to fossil products, the production stage of bio-based products can offer various advantages. Carus et al. (2017) use the example of smart drop-ins to emphasize that the production of bio-based products can require significantly less energy than fossil products. To adequately demonstrate this advantage, it is proposed to consider a certain criterion for the energy efficiency of the production process. Specific advantages of biobased products could be demonstrated by a criterion that compares the energy consumption with a conventional benchmark product.

\section{Biomass Utilization Efficiency}

The biomass utilization efficiency (BUE) factor was developed by Iffland et al. (2015). It is defined as "percentage of initial biomass ending up in the end product based on the molar mass of the reactant (= biomass) and target bio-based product." STAR-ProBio (2017) also identified the efficiency of biomass utilization as a specific assessment gap. As described earlier, the Cradle to Cradle ${ }^{\circledR}$ scheme considers the use of materials in the production. In this context, there are attractive opportunities to include assessment criteria to highlight the benefits of certain bio-based products. For example, the bio-based polyester PLA (polylactic acid) and the acid SA (succinic acid) show a highly efficient material use of biomass (Iffland et al., 2015). These cases show the attractiveness of a BUE criterion.

\section{Life Cycle Cost}

An additional economic criterion is life cycle cost (LCC). According to Vertech (2014), LCC is a method for evaluating all relevant costs over time of a project, product, or measure (e.g. initial costs, future costs and any resale, salvage, or disposal cost). Bio-based products can provide various 
cost advantages. The above-mentioned Cradle to Cradle ${ }^{\circledR}$ concept combines environmental, social and specific economic factors and aims at "designs that are positive or beneficial in terms of cost, performance, (...), and material (re)utilization potential with continuous use and reuse periods" $(\mathrm{C} 2 \mathrm{C}$, 2016). In order to highlight the specific advantages of bio-based products, economic analyses with a focus on LCC are particularly suitable.

\section{ADDITIONAL CRITERIA}

\section{Bio-based content}

The specification CEN/TS 16137:2011 (Plastics - Determination of bio-based carbon content, CEN 2011) requires minimum bio-based content. It expresses the bio-based carbon content as a fraction of the sample mass, or the total carbon/organic carbon content. Bio-based content is already required by some ecolabels. One example of the product labelling of bio-based content is the EU Ecolabel.

\section{Fitness for Use}

Performance and functionality are key product characteristics. For this reason, the criterion of 'fitness for use' is included in several ecolabels. The performance of bio-based products and their properties compared to conventional ones is the subject of differentiated opinions. According to STAR-ProBio (2017), some stakeholders are divided regarding this issue. To counteract this and to facilitate comparisons with traditional fossil-based products, a functionality/performance criterion could be of great value to strengthen confidence in bio-based products. In order to minimise the labelling effort, the use of such a criterion could be voluntarily and product specific.

\section{ECOLABEL CRITERIA AND LABELS FOR SELECTED BIO-BASED PRODUCTS}

Based on the preliminary work and the evaluation criteria, a series of case-study-specific interviews were conducted. The analysis led to various conclusions. In the following, they are presented focusing on the significance of ecolabel criteria and their implications for ecolabels.

\section{Significance of Ecolabel Criteria}

Table 3, which is based on 22 expert interviews, provides an overview of the relevance of the criteria determined in the previous chapter for the four applications of bio-based products.

While criteria related to sustainable biomass/bio-based content, end-of-life options and social corporate responsibility are mostly advocated in the interviews, the criteria for life cycle analyses, especially with regard to costs, were less frequently selected. The results also show numerous differences between the case studies. The interviewees in the automotive sector generally selected sets of criteria with fewer elements.

In contrast to the automotive sector, the majority of respondents in the other three sectors suggested in particular that fitness for use/usability should be included in the list of ecolabel criteria for the products. The reason for the dominating opt-outs in the automotive sector is that this aspect is assessed much earlier in the vehicle life cycle than it would be for the award of an ecolabel. Components that do not meet the necessary functional requirements are discarded early in the development or manufacturing process. Another observation was that the automotive components under consideration are primarily not products with special functions that are demanded separately by end customers.

Although the criterion of energy demand in production has gained $50 \%$ approval in the automotive sector, a higher percentage rate was not reached. It was pointed out, for example, that the energy balance of bio-based composites is better than that of carbon alternatives. The most important reason why the results did not reach the even higher values in the other areas, however, is that the stakeholders in the automotive industry want a more specific criterion. The separate consideration of 
Table 3. Relevance of selected ecolabel criteria in the case studies

\begin{tabular}{|c|c|c|c|c|}
\hline \multirow[t]{2}{*}{$\begin{array}{l}\text { Assessment } \\
\text { Criteria }\end{array}$} & \multicolumn{4}{|c|}{$\begin{array}{l}\text { Relevance for ecolabels for the case study products } \\
\text { according to interviews }\end{array}$} \\
\hline & $\begin{array}{l}\text { Bio-based car } \\
\text { components }^{4}\end{array}$ & $\begin{array}{l}\text { PLA/Food } \\
\text { packaging }\end{array}$ & $\begin{array}{l}\text { Mulch } \\
\text { Films }\end{array}$ & $\begin{array}{l}\text { Insulation } \\
\text { materials }\end{array}$ \\
\hline \multicolumn{5}{|c|}{ Sustainable biomass / bio-based content } \\
\hline \multicolumn{5}{|c|}{$\mathrm{CO}_{2}$ emissions } \\
\hline \multicolumn{5}{|l|}{ Toxicity } \\
\hline \multicolumn{5}{|c|}{ End-of-life options } \\
\hline \multicolumn{5}{|c|}{ Fitness for use } \\
\hline \multicolumn{5}{|c|}{ Corporate social responsibility } \\
\hline \multicolumn{5}{|c|}{ Fundamental principles \& rights at work } \\
\hline \multicolumn{5}{|c|}{ Energy requirement during production } \\
\hline \multicolumn{5}{|c|}{ Biomass utilisation efficiency } \\
\hline \multicolumn{5}{|c|}{ Life cycle values } \\
\hline \multicolumn{5}{|c|}{ Life cycle costing specifically } \\
\hline \multicolumn{5}{|c|}{$\begin{array}{l}\text { Note: Interviewees also made specific additional suggests for criteria, in particular related to land use and use } \\
\text { of water }\end{array}$} \\
\hline \multicolumn{5}{|c|}{$\begin{array}{l}\text { relevant in }>50 \% \text { of the interviews } \\
\text { not relevant in }>50 \% \text { of the interviews } \\
\text { alternatively, a suggestion for a modification was made } 50 \% \text { of the interviews }\end{array}$} \\
\hline $\begin{array}{l}4 \text { Side doors } \\
\text { bio-based } r \\
\text { interiors } m\end{array}$ & $\begin{array}{l}\text { materials using } r \\
1 \text { covers made of } \\
\text { natural fibres. }\end{array}$ & $\begin{array}{l}\text { tural fibres s } \\
\text { bio-based pol }\end{array}$ & $\begin{array}{l}\mathrm{h} \text { as flax, } \\
\text { mides/PI }\end{array}$ & $\begin{array}{l}\text { linen and a } \\
\text { c) car }\end{array}$ \\
\hline
\end{tabular}

the use of renewable or non-renewable energies would represent for the interviewees, a more suitable assessment alternative.

In two case studies (for automotive components and bio-based mulch films), the efficiency of biomass use is only supported by $50 \%$ of the respondents as a possible evaluation criterion. The interviewees in the automotive sector emphasized that the high technical requirements, especially for functional and external vehicle components, clearly determine which material and which biomass is suitable. A material with optimum BMU values does not necessarily have the properties and quality required in the automotive industry. For this reason, the BMU criterion has a lower priority there, but should not be ignored according to the interview series.

The criterion "basic principles and rights at the workplace" was selected by the majority in the interviews in three of the four case studies, while the deviation in the automotive sector is minor. The interviewees of the automotive sector also confirmed the importance of the topic, but suggested, for example, an assessment at the company level or the use of a compressed criterion on social aspects.

\section{Implications for Ecolabels and Standardization}

With regard to the four case studies, specific implications were derived: 
Regarding PLA, including a criterion "bio-based packaging" in the criteria lists of the labels relevant for food packaging is recommended - but not only for this area. It is recommended everywhere, where bio-based packaging is feasible. This applies in particular to paper packaging or paper bags with plastic windows, which can alternatively be made of bio-based plastics. Details are discussed in STAR-ProBio (2018a). A suitable label could be provided, for example, by extending the scope of application of the FSC®/PEFC label to bio-based plastic components. In addition, the results on the criteria for the ecolabel support the possible joint labelling initiative of the EU ecolabel and the organic label in the food sector described with further suggestions from Scuola Superiore Sant' Anna and Ökoinstitut (2018). Interviewed experts argue that a specially proposed LCA standard should facilitate comparisons with products made of conventional materials in order to identify advantages of bio-based versions and overcome price-related disadvantages of PLA.

New segments of bio-based components are developing in the automotive industry, although there are hardly any possibilities for obtaining ecolabels to communicate the corresponding positive product characteristics. With a focus on the selected components of our analysis, it is proposed to close this gap parallel to market development through measures to provide a suitable ecolabel. One interviewee described such a potential offer as an effective way to provide transparent information to customers. Standardisation measures have been proposed by experts with regard to end-of-life sustainability and energy issues. Concerning the end-of-life aspect, recyclability should be a key issue. Similar to the case study on food packaging, special attention was paid to life cycle assessments and comparisons with fossil products in the information provided.

Concerning bio-based, biodegradable mulch films, it makes sense to create a specific set of ecolabel criteria for advanced product evaluation. According to expert opinion, there are four main aspects to consider: 1 . bio-based content/composition of the product, 2 . sustainability of the raw materials, 3. functionalities (third-party certification according to EN 17033) and 4. biodegradability in the soil as the only end-of-life option. The biodegradability of bio-based mulch films, their specific requirements and suitable test methods are already taken into account in the new standard EN 17033:2018. In addition, most respondents emphasised the functional properties of bio-based, biodegradable mulch films as an important field of action for standardisation. Briassoulis and Giannoulis (2018) provide further information on the specification of functional properties.

In the case of bio-based insulating materials, the "natureplus" label, which was the subject of the interview, already had an international ecolabel that takes into account many aspects of sustainability that are regarded as important for bio-based products. Based on the suggestion of a minimum percentage for bio-based material criteria, additional suggestions for the introduction of criteria for durability (product lifetime), functionality and performance were made in the interviews. Challenges are perceived by stakeholders regarding the introduction of unconventional or alternative products, including bio-based forms, into the construction sector. According to the interviews, the creation of EU standards for bio-based construction products could provide support for this issue. In addition, a revision of some currently established test methods can help to demonstrate several positive effects of bio-based insulation materials such as vapour permeability and heat storage capacity. It is also considered necessary to redefine the life cycle values for some bio-based products.

\section{Contribution to the SDGs}

The discussed suggestions for ecolabels in this article are linked with the SDGs in various ways. Table 4 lists the ecolabel criteria and additional items identified in our study with corresponding columns showing which SDGs it contributes to.

The requirement for sustainable biomass addresses SDG 2, target 2.4, which aims at the implementation of resilient agricultural practices that help maintain ecosystems and strengthen capacity for adaptation to climate change. The toxicity criterion addresses Goal 3, target 3.9 on a substantial reduction of the number of deaths and illnesses from hazardous chemicals, pollution and contamination. The energy requirement during production and the use of sustainable energy are in 
Table 4. Consideration of the SDGs by the selected ecolabel criteria

\begin{tabular}{|c|c|c|c|c|}
\hline $\begin{array}{l}\text { Ecolabel assessment item, } \\
\text { identified by this research }\end{array}$ & $\begin{array}{l}\text { SDG(s) addressed by } \\
\text { the criterion }\end{array}$ & $\begin{array}{l}\text { Ecolabel assessment } \\
\text { item, identified by this } \\
\text { research }\end{array}$ & $\begin{array}{l}\text { SDG(s) a } \\
\text { the criter }\end{array}$ & $\begin{array}{l}\text { ddressed by } \\
\text { rion }\end{array}$ \\
\hline Corporate social responsibility & 1 mover & \multirow{2}{*}{ End-of-life options } & 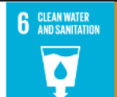 & 12 \\
\hline $\begin{array}{l}\text { Sustainable biomass/ bio- } \\
\text { based content / land use, } \\
\text { Biomass utilisation efficiency }\end{array}$ & 2 & & $14 \underset{14 \text { UEt }}{\approx} \approx$ & 15 ofr \\
\hline Fitness for use, Toxicity & 3 coopheatr & Life cycle costing & 8 ogengurosano & 9 mostringoun \\
\hline $\begin{array}{l}\text { Fundamental principles and } \\
\text { rights at work }\end{array}$ & 5 GrogR & $\begin{array}{l}\text { Corporate social } \\
\text { responsibility, } \\
\text { Fundamental principles } \\
\text { and rights at work }\end{array}$ & 10 Rroucen & \\
\hline $\begin{array}{l}\text { Energy requirement during } \\
\text { production, modified for } \\
\text { sustainable energy }\end{array}$ & 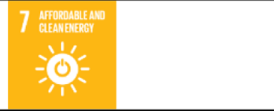 & $\begin{array}{l}\mathrm{CO}_{2} \text { emissions, Life cycle } \\
\text { values }\end{array}$ & 11 Minowarentis & 13 gumane \\
\hline
\end{tabular}

line with target 7.3, which requires to double the global rate of improvement in energy efficiency by 2030. Finally, the criteria on end-of-life options and Life Cycle Assessments address, for example target SDG 12.4, requiring the environmentally sound management of all wastes throughout their life cycle, and to reduce their release to air, water and soil in order to minimize their adverse impacts significantly by 2030 (Sustainable Development Solutions Network, SDSN). The above-mentioned examples show the relationship between the table's assessment items and the SDGs.

\section{THE WAY FORWARD}

\section{Implications for Policy Makers and Practitioners}

Open-Bio (2016), El-Chichakli et al. (2016) and various other authors have demonstrated the variety of environmental and SDG-related advantages that bio-based products can provide. They have shown for example that various bio-based products have a lower $\mathrm{CO}_{2}$ footprint in production than alternative fossil products as an environmental benefit as well as the contribution of the bio-economy to society and economic growth.

Based on the criteria identified and presented in this article, environmental, social and economic advantages of bio-based products can be demonstrated by ecolabels. Besides suggesting criteria, this article even suggests the introduction of new ecolabel categories.

However, these advantages of labelled products and their contribution to the SDGs can only materialize, if these products are bought indeed. Therefore, it will not only be important to appropriately support this article's suggested ecolabel activities but also to provide additional support by introducing supportive marketing measures.

Besides ecolabels as whole, several single criteria of this article have specific importance. An issue, which is of high world-wide concern and influences policy making and economic behaviour of businesses globally is $\mathrm{CO}_{2}$. The suggested $\mathrm{CO}_{2}$ criterion of this article provides opportunities to show specific advantages of bio-based products in this context, which might help to stimulate their demand significantly. However, specific measures will be necessary to sensitise the public for this aspect and the relevant product information based on ecolabels. 


\section{Implications for Research}

Based on this article's suggestions for ecolabels, various questions regarding their future use and impact emerge. Lanzini et al. (2016) formulated precise research and policy-related suggestions regarding ecolabels for biofuels. In this context they highlight that previous studies have demonstrated the positive role of certification in promoting the sale of green products. For this reason, they suggest exploring the link between the willingness to pay (for labelled biofuels) and the familiarity with other (non-sector-specific) forms of certification in other markets. Likewise, we suggest further research on ecolabels for bio-based products in the four areas of our research and their influence on the willingness to pay.

\section{CONCLUSION}

Using ecolabelling as an instrument to show specific environmental and societal advantages of biobased products is currently a research gap.

In this article, the suitability of different ecolabel criteria for bio-based products was assessed based on specific case studies. Options for modified ecolabel criterion sets were identified and suggestions for new labelling offers were given. Thus, the identification of modifications to the set of ecolabel criteria and the offer of new labels for bio-based products can increase environmental knowledge and increase consumer concerns, ultimately, resulting in environmentally friendly consumption behavior, according to research by Daugbjerg et al. (2014). The article showed key criteria that are relevant not only for ecolabels but also for further activities to promote market development for bio-based products and also identified links of these criteria with the SDGs. With regards to their future use, it was highlighted that specific indicators and the setting of thresholds require further investigation. The analyses also showed the importance of taking product-specific characteristics into account when assessing the sustainability of bio-based products and emphasised the need to adapt the assessment solutions to the corresponding markets (business-to-business, -to-consumer and -togovernment), e.g. in the automotive sector. Corresponding needs for standards were also identified, including for example the introduction of LCA standards for facilitating comparisons with products made of conventional materials in order to identify advantages of bio-based versions and overcome their price-related disadvantages.

Product-specific properties and applications also impact the individually relevant end-of-life options, e.g. in terms of favouring biodegradability and compostability. CE Delft (2017) showed that the use of biodegradable bio-based plastics is recommended above all in applications with direct functional advantages or a clear additional benefit. In the context of the presented case studies, this direct functionality refers in particular to biodegradable mulch films, which eliminate the need to remove the films from the fields after use.

Many specific results of the case studies are relevant for the whole bioeconomy, including for example: the importance of criteria sustainable biomass, minimum bio-based content, reduction of $\mathrm{CO}_{2}$ emissions, end-of-life options and corporate social responsibility. In addition, it was reiterated that the realisation of a sustainable bio-based economy requires the engagement of all stakeholders.

It is proposed to follow up the development of this article's proposals for the ecolabel landscape and in particular to analyse how they will contribute to innovation in the bio-economy. Therefore, it seems important to deepen and extend the results of the analysis shown here through further research. Questions on the sustainability of selected bio- and cycle-based automotive components, for example, will be addressed in the above-mentioned project ConCirMy. 


\section{REFERENCES}

Adams, W. (2015). Conducting Semi-Structured Interviews. In J. Wholey \& H. Hatry, K. (Eds.), Newcomer: Handbook of Practical Program Evaluation (4th ed., pp. 492-505). Hoboken, NY: Jossey-Bass. doi:10.1002/9781119171386.ch19

Asdrubali, F., D'Allessandro, F., \& Schiavoni, S. (2015). A review of unconventional sustain-able building insulation materials. Sustainable Materials and Technologies, 4, 1-17.

BIO Intelligence Service. (2012). Policies to encourage sustainable consumption. Technical Report. Paris, France: European Commission (DG ENV).

Biobased Industries Consortium. (2018). Bioeconomy and the UN Sustainable Development Goals. Retrieved from https://biconsortium.eu/sites/biconsortium.eu/files/documents/Bioeconomy_and_the_SDGs_July\%202018.pdf

Briassoulis, D., Hiskakis, M., Babou, E., .... (2012). Experimental Investigation of the Quality Characteristics of Agricultural Plastic Wastes Regarding their Recycling and En-ergy Recovery Potential Waste Management: In: Waste Management, 32(2012), 1075-1090

Carus, M., Dammer, L., Puente, Á., Raschka, A., \& Arendt, O. (2017). Bio-based drop-in, smart drop-in and dedicated chemicals. Roadtobio. Retrieved from https://www.roadtobio.eu/uploads/news/2017_October/ RoadToBio_Drop-in_paper.pdf

CE Delft. (2017). Biobased Plastics in a Circular Economy Policy suggestions for biobased and biobased biodegradable plastics. Retrieved from https://www.cedelft.eu/publicatie/biobased_plastics_in_a_circular_ economy/2022

CEN (2011). CEN/TS 16137:2011. Plastics - Determination of bio-based carbon content

CEN (2014). EN 16575:2014. Bio-based products - Vocabulary

CEN (2015). EN 16760:2015. Bio-based products - Life Cycle Assessment.

CEN-CENELEC. (2013). Annual report CEN CENELEC 2013. Retrieved from https://www.cencenelec.eu/ News/Publications/Publications/AR2013_CEN_EN_final.pdf

Cradle to Cradle Products Innovation Institute (C2C). (2016). Cradle to Cradle Certified. Product Standard Version 3.1. Retrieved from https://s3.amazonaws.com/c2c-website/resources/certification/standard/STD C2CCertified_ProductStandard_V3.1_082318.pdf

Daugbjerg, C., Smed, S., Andersen, L. M., \& Schvartzman, Y. (2014). Improving eco-labelling as an environmental policy instrument: Knowledge, trust and organic consumption. Journal of Environmental Policy and Planning, 16(4), 559-575. doi:10.1080/1523908X.2013.879038

Ecolabel Index. (2018). Ecolabel Index. Retrieved from http://www.ecolabelindex.com/

EIA. (2015). Who Watches the Watchman? Auditors and the breakdown of oversight in the RSPO. Retrieved from https://eia-international.org/wp-content/uploads/EIA-Who-Watches-the-Watchmen-FINAL.pdf

El-Chichakli, B., von Braun, J., Lang, C., Barben, D., \& Philip, J. (2016). Five cornerstones of a global bioeconomy. Nature, 535(7611), 221-223. doi:10.1038/535221a PMID:27411618

European Commission (2012). Innovating for Sustainable Growth - A Bioeconomy for Europe. Brussels, Belgium: EC.

European Commission. (2015). 4th Foresight Exercise Sustainable Agriculture, Forestry and Fisheries in the Bioeconomy - A Challenge for Europe. Retrieved from https://ec.europa.eu/research/scar/index. cfm?pg=foresight 4 th

European Commission (2018a). Environmental Impact Assessments of Innovative Bio-Based Products. Brussels, Belgium: EC.

European Commission. (2018b). Energy. Retrieved from https://ec.europa.eu/energy/en/topics/renewable-energy/ biofuels/sustainability-criteria 
FNR. (2017). Nachwachsende Rohstoffe im Einkauf, Themenheft III: Büro - Einrichtung, Material, Gestaltung. Retrieved from https://mediathek.fnr.de/broschuren/nachwachsende-rohstoffe/nachhaltige-beschaffung.html

FNR. (2019). Umweltzeichen. Retrieved from https://beschaffung.fnr.de/

Gawel, E., Pannicke, N., \& Hagemann, N. (2019). A Path Transition Towards a Bioeconomy- The Crucial Role of Sustainability. Sustainability, 11(11), 3005. doi:10.3390/su11113005

GlobeScan. (2012). Re:thinking consumption. Consumers and the future of sustainability. Retrieved from https:// www.globescan.com/component/edocman/?task=document.viewdoc\&id=51\&Itemid=0

Heimann, T. (2019). Bioeconomy and SDGs: Does the Bioeconomy Support the Achievement of the SDGs? Earth's Future, 7(1), 43-57. doi:10.1029/2018EF001014

Horne, R. E. (2009). Limits to labels: The role of eco-labels in the assessment of product sustainability and routes to sustainable consumption. International Journal of Consumer Studies, 33(2), 175-182. doi:10.1111/j.14706431.2009.00752.x

Ibanez, L. (2016). ECOLABELS: Are They Environmental-Friendly? In A. Marciano \& G.B. Ramello (Eds.), Encyclopedia of Law and Economics. Springer Science+Business Media.

IfBB. (2018). Hannover Messe: Niedersachsens Wissenschaftsminister Thümler informiert sich am Stand des IfBB. Retrieved from https://www.ifbb-hannover.de/de/nachricht/hannover-messe-niedersachsenswissenschaftsminister-thuemler-informiert-sich-am-stand-des-ifbb.html

Iffland, K., Sherwood, J., \& Carus, M. (2015). Definition, Calculation and Comparison of the "Biomass Utilization Efficiencies (BUE)" of Various Bio-based Chemicals, Polymers and Fuels, Retrieved from http:// bio-based.eu/nova-papers/

ILO/ITC. (2007). International Instruments and Corporate Social Responsibility. A Booklet to Accompany Training on Promoting labour standards through Corporate Social Responsibility. Retrieved from https://www.ilo. org/wcmsp5/groups/public/---ed_emp/---emp_ent/---multi/documents/instructionalmaterial/wcms_227866.pdf

ISO. (2006). ISO 14040:2006. Environmental management - Life cycle assessment - Principles and framework, ISO 14044 Environmental Management - Life Cycle Assessment - Requirements and Guidelines

ISO. (2012). Environmental labels and declarations - How ISO standards help. Geneva, Switzerland: ISO.

ISO (2013). ISO 472:2013. Plastics -- Vocabulary

ISO. (2018a). Contributing to the UN Sustainable Development Goals with ISO standards. Geneva, Switzerland: ISO.

ISO. (2018b). ISO and Climate Change. Geneva, Switzerland: ISO.

ISO. (2018c). ISO 14024 on Environmental labels and declarations - Type I environmental labelling - Principles and procedures. Geneva, Switzerland: ISO.

Ladu, L., \& Blind, K. (2017). Overview of policies, standards and certifications supporting the European biobased economy. Current Opinion in Green and Sustainable Chemistry, 8, 30-35. doi:10.1016/j.cogsc.2017.09.002

Lanzini, P., Testa, F., \& Iraldo, F. (2016). Factors affecting drivers' willingness to pay for biofuels: The case of Italy. Journal of Cleaner Production, 112, 2684-2692. doi:10.1016/j.jclepro.2015.10.080

Nunes, A. R., Lee, K., \& O'Riordan, T. (2016). The importance of an integrating framework for achieving the Sustainable Development Goals: the example of health and well-being. BMJ Global Health.

OECD (1995). Eco-labels: The Industrialisation of Environmental Standards. The Ecologist, 25(1).

OECD (2005). Effects of Eco-Labelling Schemes: Compilation of Recent Studies. Retrieved from http://www. oecd.org/officialdocuments/publicdisplaydocumentpdf/?doclanguage $=$ en $\&$ cote $=$ com/env/td(2004)34/final

Open-Bio (2016). Deliverable $N^{\circ}$ 7.3: Proposal on eco-criteria for bio-based products. Public summary. 
PEFC. (n.d.). Vom Wald zum Produkt. Die PEFC-CHAIN-OF-CUSTODY - So funktioniert der Produktkettennachweis. Retrieved from https://pefc.de/media/filer_public/2d/38/2d385cb6-a7be-409a-8dfafb8e330b4a3e/tmppefc_coc-broschuere.pdf

Peuckert, J., \& Quitzow, R. (2017). Acceptance of bio-based products on business-to-business markets and public procurement: Expert survey results. Biofuels, Bioproducts \& Biorefining, 11(1), 92-109. doi:10.1002/bbb.1725

Schrader, U., \& Thøgerse, J. (2011). Putting Sustainable Consumption into Practice. Journal of Consumer Policy, 34(1), 3-8. doi:10.1007/s10603-011-9154-9

STAR-ProBio. (2017). STAR-ProBio Deliverable D1.1. Report on identified environmental, social and economic criteria/ indicators/requirements and related "Gap Analysis".

STAR-ProBio. (2018a). STAR-ProBio Deliverable D9.2, Recommendations for Standards and criteria for eco-labels for bio-based products. Retrieved from http://www.star-probio.eu/wp-content/uploads/2017/04/ STAR-ProBio_D9.2_final.pdf

STAR-ProBio. (2018b). STAR-ProBio Deliverable D7.1. Examination of existing iLUC approaches and application to bio-based materials. Retrieved from http://www.star-probio.eu/wp-content/uploads/2017/04/ Attachment_0-3.pdf

TNS. (2012). FLASH EUROBAROMETER 367 “Attitudes of Europeans Towards Building the single market for green products." Retrieved from http://ec.europa.eu/environment/eurobarometers_en.htm

UBA. (2018). Nachhaltigkeitsstandards / Zertifizierung von Biomasse. Retrieved from https://www. umweltbundesamt.de/nachhaltigkeitsstandards-zertifizierung-von

United Nations. (1992). Agenda 21. Retrieved from https://sustainabledevelopment.un.org/outcomedocuments/ agenda 21

United Nations. (2015). Transforming Our World: The 2030 Agenda for Sustainable Development. New York: UN.

USDA. (2018). Biopreferred. Retrieved April 2, 2019, from https://www.biopreferred.gov/

Vertech Group (2014). Life Cycle Cost Assessment.

WFP. (2019). Energy for Food Security - Enhancing people's food security with improved energy access. Italy: WFP.

Wurster, S., Ladu, L., \& Majer, S. (2018). Förderung biobasierter Produkte durch Normung und Zertifizierung. Horizon-2020-Projekt STAR-ProBio - Bisher Erreichtes, Handlungsbedarf und Lösungsansätze. DIN Mitteilungen, (4), 13-21. 
Simone Wurster holds a PhD from the University of Potsdam in economics and social sciences and is a senior researcher and project manager at the chair of Innovation Economics at TUB. Enriched by her experience as a project manager and consultant for technology companies, her research focuses on innovation economics, technology management and the sustainable economy. The technical areas of her specialisation include the bio-based and circular economy, information technologies and digitalization including blockchain, early warning systems as well as privacy and data protection. She has taken part in various national and EU-level research projects as project leader, work package leader and sub-project leader including CRISP, STAR-ProBio, ConCirMy, INFRANORM, ENSURE, BlockOne among many others. Simone has published two books as well as numerous articles and papers, among them two award-winning contributions and also coordinated the development of two DIN standards (DIN SPECS).

Luana Ladu (Ms.) holds a M. Sc. in Economics from UFBA (Brazil) and a Degree in Law and Business Administration (Master equivalent) from Bocconi University (Italy). She has several years of experience as consultant and researcher in the field of international development and sustainable development, with a focus on sustainability, circularity and bio-based economy. She is currently working as a Research Fellow at the Chair of Innovation Economics of the Technische Universität Berlin in the framework of the STARPROBIO, STAR4BBI and Bio Top projects, where she is responsible for the implementation of different foresight exercises (including scenario development and Delphi surveys), regulatory framework analysis and market studies. She is also pursuing a PHD in economics, planned to be finalized by June 2020. A list of her current publications is available at: https://www. inno.tu-berlin.de/menue/about_us/team/luana_ladu_msc/parameter/de/Ms. Ladu has many years of professional experiences abroad, including 3 years as a consultant at the ICT for Development Division of the Inter-American Development Bank (IADB), developing and implementing its "ICT in Governance and ICT security for the public sector" program as well as its ICT strategy entitled "Connecting the Majority." During her professional experience as project manager and project director in a consulting firm, she was involved in the implementation of numerous donor finance projects in the field of Education, Vocational Training and Capacity Building sector.

Dhandy Arisaktiwardhana obtained his Bachelor's degree in Electrical Engineering in 2001. In 2012, he completed his Master's degree in Electricity and Energy Management. He has 17 years working experience in the field of standardization and conformity assessment. His current research area is standardization, conformity assessment, climate change and sustainable development. 